https://helda.helsinki.fi

Lignin-degrading activity and ligninolytic enzymes of different white-rot fungi : effects of manganese and malonate

\title{
Vares, $\mathrm{T}$.
}

National Research Council Canada

1997

Canadian Journal of Botany. 75: 61-71

http://hdl.handle.net/1975/906

http://dx.doi.org/

Downloaded from Helda, University of Helsinki institutional repository.

This is an electronic reprint of the original article.

This reprint may differ from the original in pagination and typographic detail.

Please cite the original version. 


\title{
Lignin-degrading activity and ligninolytic enzymes of different white-rot fungi: effects of manganese and malonate
}

\author{
Tamara Vares and Annele Hatakka
}

\begin{abstract}
Ten species of white-rot fungi, mainly belonging to the family Polyporaceae (Basidiomycotina), were studied in terms of their ability to degrade ${ }^{14} \mathrm{C}$-ring labelled synthetic lignin and secrete ligninolytic enzymes in liquid cultures under varying growth conditions. Lignin mineralization by the fungi in an air atmosphere did not exceed $14 \%$ within 29 days. Different responses to the elevated $\mathrm{Mn}^{2+}$ concentration and the addition of a manganese chelator (sodium malonate) were observed among various fungal species. This could be related with the utilization of either lignin peroxidase (LiP) or manganese peroxidase (MnP) for lignin depolymerization, i.e., some fungi apparently had an LiP-dominating ligninolytic system and others an MnP-dominating ligninolytic system. The LiP isoforms were purified from Trametes gibbosa and Trametes trogii. Isoelectric focusing of purified ligninolytic enzymes revealed the expression of numerous $\mathrm{MnP}$ isoforms in Trametes gibbosa, Trametes hirsuta, Trametes trogii, and Abortiporus biennis grown under a high (50-fold) $\mathrm{Mn}^{2+}$ level $(120 \mu \mathrm{M})$ with the addition of the chelator. In addition, two to three laccase isoforms were detected.
\end{abstract}

Key words: white-rot fungi, lignin degradation, lignin peroxidase, manganese peroxidase, manganese, malonate.

Résumé : Les auteurs ont étudié 10 espèces de champignons de carie blanche, appartenant surtout à la famille des Polyporaceae (Basidiomycotina), afin de déterminer leur capacité à dégrader la lignine synthétique avec anneaux ${ }^{14} \mathrm{C}$ marqués et à secréter des enzymes cellulolytiques en milieu de culture liquide, sous différentes conditions de croissance. La minéralisation de la lignine par les champignons, dans l'air atmosphérique, n’a pas dépassé $14 \%$ en 29 jours. On observe différentes réactions aux concentrations élevées de $\mathrm{Mn}^{2+}$ et à l'addition d'un chélateur du manganèse (malonate de sodium) parmi les différentes espèces fongiques. On peut relier ceci à l'utilisation, soit de la peroxydase de la lignine (LiP) ou soit à la peroxydase du manganèse $(\mathrm{MnP})$ pour la dépolymérisation de la lignine, i.e., certains champignons possèdent apparemment un système ligninolytique dominé par la LiP et d'autres par la $\mathrm{MnP}$. Les isoformes de la $\mathrm{LiP}$ ont été purifiées à partir du Trametes gibbosa et du Trametes trogii. La focalisation isoélectrique des enzymes ligninolytiques purifiés montre l'expression de nombreuses isoformes de la $\mathrm{MnP}$ chez les Trametes gibbosa, Trametes hirsuta, Trametes trogii et l'Abortiporus biennis cultivés en présence de fortes teneurs (50 fois) de $\mathrm{Mn}^{2+}(120 \mu \mathrm{M})$ avec addition du chélateur. On a en plus détecté la présence de deux ou trois isoformes de laccase.

Mots clés : champignon de carie blanche, dégradation de la lignine, peroxydase de la lignine, peroxydase manganique, manganèse, malonate.

[Traduit par la rédaction]

\section{Introduction}

The terms lignin-degrading or white-rot fungi designate a group of taxonomically heterogeneous higher fungi, characterized by their unique ability to depolymerize and mineralize lignin using a set of extracellular ligninolytic enzymes. These fungi are mainly saprophytes and belong to the orders Aphyllophorales and Agaricales (Basidiomycotina) (1). The origin of white-rot fungi dates back to the Carboniferous period and is closely linked with the formation of forests, since wood is the natural substrate for these species (13). The mechanism of lignin degradation by white-rot fungi has been

Received March 6, 1996.

T. Vares and A. Hatakka. ${ }^{1}$ Department of Applied Chemistry and Microbiology, P.O. Box 56 (Biocenter 1), FIN-00014 University of Helsinki, Finland.

Author to whom all correspondence should be addressed. e-mail: Annele.Hatakka@HELSINKI.FI intensively studied during the last 20 years in relation to biotechnical applications such as biopulping, biobleaching, treating of pulp mill effluents, and soil bioremediation $(24,28,30,31,41)$. The molecular biology of lignin degradation was mainly determined in the white-rot fungus Phanerochaete chrysosporium (12). To date, compared with other ligninolytic microorganisms, Phanerochaete chrysosporium is much better characterized because the two ligninmodifying extracellular peroxidases, lignin peroxidase (LiP, EC 1.11.1.14) and manganese peroxidase (MnP, EC 1.11.1.13), were first isolated from this fungus $(26,49)$. However, other species of white-rot fungi were reported to degrade lignin as efficiently as Phanerochaete chrysosporium $(5,15,35,54)$. Moreover, several fungi show better selectivity for lignin removal $(5,30,31,42)$. Physiological conditions for lignin degradation, as well as secretion patterns of the ligninolytic enzymes, vary between different fungal species (14). Probably the most intriguing question is which enzyme or enzyme combination is responsible for lignin 
Table 1. Description of the fungal strains.

Type of wood substrate in nature*

\begin{tabular}{|c|c|}
\hline \multicolumn{2}{|l|}{ Polyporaceae* } \\
\hline Abortiporus biennis (Bull. ex Fr.) Sing. ${ }^{\dagger}$ & Gymnosperms and angiosperms \\
\hline Cerrena unicolor (Fr.) Murr. ${ }^{\ddagger}$ & Angiosperms \\
\hline Junghuhnia separabilima (Pouz.) Ryv. ${ }^{\S}$ & Angiosperms \\
\hline Trametes gibbosa (Pers.) Fr. ${ }^{\S}$ & Angiosperms, preferably Fagus \\
\hline Trametes hirsuta (Fr.) Pilat $^{\dagger}$ & Angiosperms \\
\hline Trametes pubescens $(\mathrm{Fr}.) \mathrm{Pilat}^{\dagger}$ & Angiosperms \\
\hline Trametes trogii Berk. $\$$ & Mainly on Populus tremula \\
\hline Trametes versicolor (L. ex Fr.) Pilat PRL $572^{1}$ & Angiosperms \\
\hline Trichaptum abietinum (Fr.) Ryv. ${ }^{\S}$ & Preferably on Picea \\
\hline \multicolumn{2}{|l|}{ Ganodermataceae* } \\
\hline Ganoderma applanatum (S.F. Gray) Pat. ${ }^{\S}$ & Angiosperms \\
\hline \multicolumn{2}{|l|}{ *According to Ryvarden and Gilbertson $(45,46)$. } \\
\hline \multicolumn{2}{|l|}{$\begin{array}{l}{ }^{\dagger} \text { Fungal strains were obtained from the culture collec } \\
\text { Academy of Science of Belarus, Minsk, Belarus. }\end{array}$} \\
\hline $\begin{array}{l}{ }^{\ddagger} \text { Fungal strains were collected in Finland, isolated at } \\
\text { and Microbiology, University of Helsinki, Helsinki, Finl }\end{array}$ & Department of Applied Chemistry \\
\hline \multirow{2}{*}{\multicolumn{2}{|c|}{$\begin{array}{l}\text { S Fungal strains were collected in Russia, isolated at the Department of Applied Chemistry } \\
\text { and Microbiology, University of Helsinki, Helsinki, Finland. }\end{array}$}} \\
\hline & \\
\hline 'Trametes versicolor PRL 572 was a gift from T. Jo & sson (Universit) \\
\hline
\end{tabular}

depolymerization, particularly with regard to the preliminary steps. In this respect, the role of $\mathrm{LiP}, \mathrm{MnP}$, and laccase (EC 1.10.3.2, benzenediol:oxygen oxidoreductase) was widely discussed and they were suggested to be the main extracellular enzymes involved in lignin modification $(14,24)$. Different white-rot fungi produce various combinations of these enzymes. Recently, on the basis of extracellular enzyme patterns, three groups of lignin-degrading fungi were proposed: $\mathrm{LiP}-\mathrm{MnP}, \mathrm{MnP}$-laccase, and $\mathrm{LiP}$-laccase producing groups (14). MnP was found in many fungal species (14) and manganese is considered to be an important factor in lignin biodegradation $(2,4,7,21,32,38-40,54)$. Free manganous ion $\mathrm{Mn}^{2+}$ is the primary substrate in the catalytic cycle of MnP (12). In the presence of an appropriate manganese chelator, a highly reactive $\mathrm{Mn}^{3+}$-chelated complex is formed that is capable of oxidizing phenolic lignin substructures $(39,56)$. Accumulation of manganese in wood, decayed by several white rot fungi under natural conditions, was described $(2,4)$.

In this paper we report the ability of 10 fungal species to mineralize and solubilize synthetic lignin (dehydrogenative polymerizate, DHP) and produce ligninolytic enzymes in liquid cultures. The influence of such regulative factors as manganese and its chelator, malonate (56), was studied. Ligninolytic enzymes ( $\mathrm{LiP}, \mathrm{MnP}$, and laccase) were purified and characterized in a number of species.

\section{Materials and methods}

\section{Fungi}

Ten different species of white-rot fungi, known to be active wooddegraders in natural environment $(3,4,6,45,46)$, were selected for investigation. These fungi cause white rot of wood and are therefore considered lignin-degrading species. Table 1 shows the taxonomical position, the natural substrate, and the origin of the fungi. Recent application of DNA sequencing methods in fungal systematics allows the phylogenetic classification of wood-decaying fungi based on both molecular and morphological characters (17). However, since this classification is not yet complete (17), here we refer to the traditional systematics based mainly on the morphological characters $(1,6,45,46)$. Species and substrate types are designated according to Ryvarden and Gilbertson $(45,46)$. Strains were maintained on malt agar $(2 \%, \mathrm{w} / \mathrm{v})$ slants.

\section{Production of extracellular ligninolytic enzymes}

To elucidate the production of extracellular ligninolytic enzymes by the fungi, preliminary studies were carried out under three different culture conditions, with or without addition of lignin-related aromatic compounds, which previously were shown to enhance secretion of lignin-modifying enzymes, particularly $\operatorname{LiP}(24,29,53)$ and laccase (29). Fungi were cultivated in 100 - $\mathrm{mL}$ flasks using basal low-nitrogen asparagine ammonium nitrate dimethylsuccinate medium $\left(2.4 \mu \mathrm{M}\right.$ of manganese as $\left.\mathrm{Mn}^{+2}\right)$, supplemented with $56 \mathrm{mM}$ glucose, $\mathrm{pH} 4.5$ (15). A-flasks contained stationary cultures (total volume of $10 \mathrm{~mL}$ ) without any inducer, cultures in the B-flasks were agitated (rotary shaker at $180 \mathrm{rpm}$ ) with the addition of $0.2 \mathrm{mM}$ veratryl alcohol (Aldrich, Steinheim, Germany) and $0.05 \%$ (w/v) Tween 80 (Fluka Chemie, Buchs, Switzerland) in a total volume of $25 \mathrm{~mL}$, and the C-flasks were stationary cultures with addition of $1.0 \mathrm{mM}$ veratric acid (Fluka Chemie, Buchs, Switzerland) in a total volume of $10 \mathrm{~mL}$ (53). Extracellular ligninolytic enzyme activities were followed in two replicate cultures starting from 2-4 days of growth. Cultures were inoculated with $4 \%(\mathrm{v} / \mathrm{v})$ mycelial suspension (15) and grown at $28^{\circ} \mathrm{C}$.

\section{Degradation of synthetic lignin (DHP)}

${ }^{14} \mathrm{C}$ ring-labelled synthetic lignin (DHP) with molecular mass of 4000 to $10000(10,54)$ was added to $100-\mathrm{mL}$ Erlenmeyer flasks (ca. $50000 \mathrm{dpm}$ in a total volume of $10 \mathrm{~mL}$ ) and evolution of ${ }^{14} \mathrm{CO}_{2}$ was monitored as described previously $(15,25)$ using a liquid scintillation counter (model 1411, Wallac Oy, Turku, Finland). To study the influence of manganese and its chelator, malonate, on DHP degradation, the following cultivation conditions were employed: (i) basal $\mathrm{Mn}^{2+}$ level $(2.4 \mu \mathrm{M})$; (ii) 50 -fold $\mathrm{Mn}^{2+}$ level $(120 \mu \mathrm{M})$; (iii) basal $\mathrm{Mn}^{2+}$ with addition of $10 \mathrm{mM}$ malonate; (iv) 50-fold $\mathrm{Mn}^{2+}$ with addition of $10 \mathrm{mM}$ malonate. 
Nonlabelled DHP (3 mg per flask; by S. Galkin, Department of Applied Chemistry and Microbiology, University of Helsinki, Finland, and G. Brunow, Deparment of Chemistry, University of Helsinki, Finland) was added to enhance ligninolytic activity. Cultures were grown without agitation under constant flow of air at $28^{\circ} \mathrm{C}$. At the end of the cultivation, culture liquids were filtered through Whatman No. 4 (Whatman, Maidstone, U.K.) on glass sinters and mycelia were washed with a total of $15 \mathrm{~mL} \mathrm{H}_{2} \mathrm{O}$. Radioactivity recovered as water-soluble products of DHP degradation, i.e., the portion of DHP not retained on the filter, was measured in liquids using a liquid scintillation counter. Mycelia and residual lignin were combusted in a combustion chamber (Junitek Oy, Turku, Finland) and the trapped ${ }^{14} \mathrm{CO}_{2}$ was quantified (15). Results are expressed as means of four replicates. Standard deviations are indicated in Fig. 2.

\section{Enzyme assays}

Ligninolytic enzyme activities were measured spectrophotometrically (Shimadzu 160A UV/visible spectrophotometer, Shimadzu, Kyoto, Japan) as described previously (29). LiP was assayed with veratryl alcohol (vacuum distilled prior to use) (50) and MnP with phenol red (Merck, Darmstadt, Germany) by monitoring the increase of absorbance at $520 \mathrm{~nm}$ in the presence of $\mathrm{Mn}^{2+}(29)$ and in the absence of $\mathrm{Mn}^{2+}$ for the peroxidase control. Laccase activity was measured with syringaldazine (Aldrich, Steinheim, Germany) (29). Protein concentration was determined with the Bradford assay (8) using a protein dye kit (Bio-Rad, Richmond, Calif.).

\section{Purification of extracellular protein}

For the purification of extracellular protein, Abortiporus biennis, Junghuhnia separabilima, Trametes hirsuta, Trametes gibbosa, and Trametes trogii were selected, since these species mineralized DHP relatively well and except for J. separabilima (52), their ligninolytic enzymes have not been studied in detail. Fungi were cultivated without agitation in 1000-mL Erlenmeyer flasks (total volume of $150 \mathrm{~mL}$ ). To enhance the production of $\mathrm{MnP}$, which obviously played an important role in DHP degradation by some of the selected species, basal medium supplemented with $1 \mathrm{mM}$ veratryl alcohol, $120 \mu \mathrm{M} \mathrm{Mn}^{2+}$, and $10 \mathrm{mM}$ sodium malonate was used in these cultivations. Extracellular culture liquids were harvested (ca. $1100 \mathrm{~mL}$ per fungus) on day 19 of growth and maintained at $-20^{\circ} \mathrm{C}$ prior to protein purification. After thawing, culture liquids were filtered through Whatman No. 4 and Whatman GF/C glass microfiber filters (Whatman, Maidstone, U.K.) and concentrated to the final volume of $10 \mathrm{~mL}$ using an Amicon (Beverly, Mass.) ultrafiltration unit (YM membrane, 10-kDa cutoff). Concentrated samples were dialyzed overnight against $25 \mathrm{mM}$ sodium acetate buffer ( $\mathrm{pH} \mathrm{5.5)}$ and applied to a Mono-Q HR column (Pharmacia Biotech., Uppsala, Sweden) equilibrated with $25 \mathrm{mM}$ sodium acetate buffer ( $\mathrm{pH} 5.5$ ). Proteins were eluted with gradient $\mathrm{NaCl}$ using an FPLC system (Pharmacia). Effluent was monitored at $280 \mathrm{~nm}$ (protein) and $405 \mathrm{~nm}$ (heme) and enzyme activities were assayed in eluted fractions.

\section{Gel electrophoresis and isoelectric focusing}

Purified ligninolytic enzymes were characterized by several gel techniques. Sodium dodecyl sulfate polyacrylamide gel electrophoresis (SDS-PAGE) and native polyacrylamide gel electrophoresis (native PAGE) (27) were carried out on $10 \%$ gels $(1 \mathrm{~mm}$ thick) using a Protean II electrophoresis unit (Bio-Rad) with gel dimensions of 16 by $20 \mathrm{~cm}$. Isoelectric focusing (IEF) was carried out using $0.5 \mathrm{~mm}$ thick polyacrylamide gels on a Multiphor II electrophoresis system (Pharmacia). The generated $\mathrm{pH}$ gradient was obtained by proportional mixing of ampholines with a $\mathrm{pH}$ range of 3.5 to 10.0 and pharmolytes with a $\mathrm{pH}$ range of 2.5 to 5.0 (Pharmacia). Gels were visualized by silver staining with Silver Stain and
Silver Stain Plus Kits (Bio-Rad) for total protein patterns and by specific activity stainings for ligninolytic enzymes, i.e., LiP and $\mathrm{MnP}$ isoenzymes were stained with phenol red at $\mathrm{pH} 4.5$ in the absence and presence of $\mathrm{Mn}^{2+}$, respectively $(37,54,55)$, and laccase activity was visualized with phenol red ( $\mathrm{pH} 4.5)$ in the absence of $\mathrm{H}_{2} \mathrm{O}_{2}$ or with guaiacol.

\section{Results}

\section{Production of ligninolytic enzymes by the fungi in low- $\mathrm{Mn}^{2+}$ medium supplemented with aromatic compounds}

Laccase was produced by many species in relatively high titers. Secretion of this enzyme increased in cultures supplemented with aromatic compounds (veratryl alcohol or veratric acid) in comparison with non-induced cultivations, e.g., the level of laccase production in the most efficient laccase producer, Cerrena unicolor, reached $10 \mathrm{nkat} \cdot \mathrm{mL}^{-1}$. In A. biennis and $J$. separabilima cultures, maximum titers of laccase activity were 1.0 and $1.6 \mathrm{nkat} \cdot \mathrm{mL}^{-1}$, respectively. Trametes gibbosa and Trametes trogii produced $0.5 \mathrm{nkat} \cdot \mathrm{mL}^{-1}$ of this enzyme. On the other hand, in Trametes hirsuta, laccase activity was not detectable under the conditions studied, but laccase was detected during subsequent purification of extracellular proteins (shown later).

LiP activity was followed in the stationary cultures of Trametes gibbosa and Trametes trogii supplemented with veratric acid, whereas in the two other growth-condition treatments only traces of LiP activity was detected. Among the fungal species studied, cultures of A. biennis, Cerrena unicolor, Trametes hirsuta, Trichaptum abietinum, and Ganoderma applanatum grown under various conditions did produce traces of LiP-like activity as detected by the veratryl alcohol oxidation method. However, since the presence of LiP was not confirmed by the other analysis (protein purification or IEF), production of LiP by these fungi needs further investigation. Three LiP isoforms from J. separabilima were previously purified by us (52), and multiple LiP isoenzymes of Trametes versicolor PRL 572 were reported by other authors $(18,19)$.

Rather high levels of MnP was detected in the stationary cultures of Trametes hirsuta with and without addition of aromatic compounds. However, due to the low- $\mathrm{Mn}^{2+}$ culture medium and insensitive MnP assay used (see Materials and methods), levels of MnP measured in culture liquids of the other fungi were not high, and in many cases it was difficult to distinguish between $\mathrm{Mn}^{2+}$-dependent $(\mathrm{MnP})$ and $\mathrm{Mn}^{2+}$-independent peroxidase activity. Subsequent purification of extracellular proteins from the high- $\mathrm{Mn}^{2+}$ cultures of five fungal species showing DHP-degrading capacity showed production of multiple $\mathrm{MnP}$ isoforms by these fungi (described later).

\section{Degradation of synthetic ${ }^{14} \mathrm{C}$ ring-labelled lignin by the fungi under altered manganese concentrations with and without malonate addition}

Among the 10 fungal species investigated, 5 fungi displayed notable DHP-degrading ability under the growth conditions used. Figure 1 shows mineralization of ${ }^{14} \mathrm{C}$ ring-labelled DHP by these species grown under low (basal) and high (50-fold) $\mathrm{Mn}^{2+}$ levels, with or without malonate addition, during the 29-day culture period in an air atmosphere. In 
Fig. 1. Mineralization of DHP by different fungi cultivated under basal $\mathrm{Mn}^{2+}(\boldsymbol{\square}), 50$-fold $\mathrm{Mn}^{2+}(\mathbf{\Delta})$, basal $\mathrm{Mn}^{2+}$ with malonate $(\bullet)$, and 50 -fold $\mathrm{Mn}^{2+}$ with malonate $(\bullet)$.
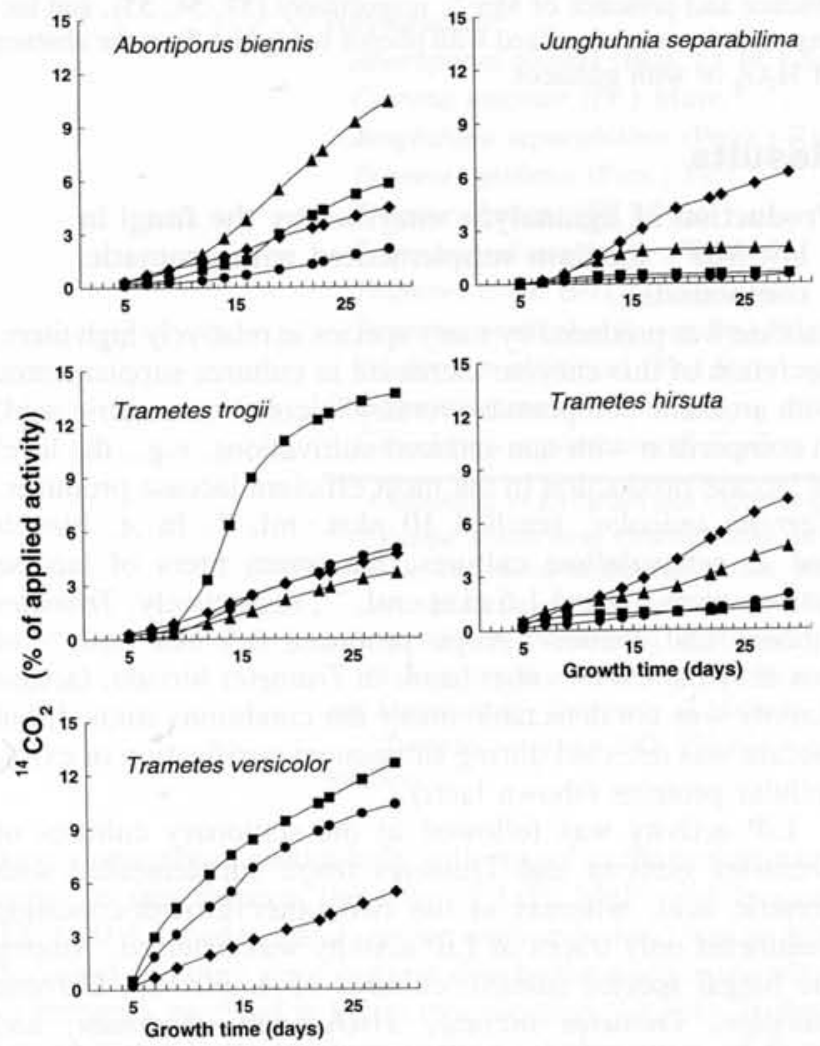

general, the percentage of DHP mineralized to $\mathrm{CO}_{2}$ by the fungi did not exceed $14 \%$ under all cultivation conditions. Results obtained with the five other fungi, which showed very low or negligible ability to mineralize DHP, are not presented in graphs. Species such as Cerrena unicolor, Trametes gibbosa, Trametes pubescens, and Trichaptum abietinum showed vigorous growth, but their capacity to mineralize DHP was very low. Ganoderma applanatum showed moderate growth and also a very low ability to degrade DHP under the conditions studied.

Fungi showed differential response to both manganese and malonate supplementation. The effect of $\mathrm{Mn}^{2+}$ addition on lignin mineralization was a stimulated evolution of ${ }^{14} \mathrm{CO}_{2}$ in cultures of many species. However, mineralization and solubilization of DHP by Trametes trogii was greater at the basal $\mathrm{Mn}^{2+}$ level compared with the high $\mathrm{Mn}^{2+}$ level (Figs. 1 and 2). In the Trametes versicolor cultures, $\mathrm{Mn}^{2+}$ seemed to repress DHP mineralization (Fig. 2). A slight increase in ${ }^{14} \mathrm{CO}_{2}$ evolution in high $\mathrm{Mn}^{2+}$ Trametes gibbosa culture was observed, but even here only about $2 \%$ of applied activity was detected as ${ }^{14} \mathrm{CO}_{2}$ (results not shown).

The supplementation of the manganese chelator sodium malonate to the low- and high-manganese cultivations induced species-specific effects on DHP degradation. In the case of A. biennis, malonate addition inhibited ${ }^{14} \mathrm{CO}_{2}$ evolution both in cultures grown under basal and 50 -fold $\mathrm{Mn}^{2+}$ concentrations (Fig. 1) but did not notably affect the amount of watersoluble products (Fig. 2). Malonate addition clearly inhibited lignin mineralization by Trametes trogii in cultures supplemented with low basal $\mathrm{Mn}^{2+}$ content, but the level of water-soluble products did not notably change. Patterns in J. separabilima and Trametes hirsuta were similar, with the highest mineralization rate occurring under 50 -fold $\mathrm{Mn}^{2+}$ and malonate (Figs. 1 and 2). In these fungi, radioactivity recovered as water-solubles was also much higher in high$\mathrm{Mn}^{2+}$ malonate cultures than in high- $\mathrm{Mn}^{2+}$ cultures without chelator (Fig. 2). In Trametes versicolor, malonate caused a slight inhibitory effect on the DHP degradation in low$\mathrm{Mn}^{2+}$ cultures (Figs. 1 and 2). In high- $\mathrm{Mn}^{2+}$ cultures of Trametes versicolor supplemented with malonate, the mineralization rate was low (Fig. 1), although radioactivity recovered as water-soluble products was as high as $18 \%$ of totally applied (Fig. 2).

Purification and characterization of ligninolytic enzymes produced in high- $\mathrm{Mn}^{2+}$ medium supplemented with veratryl alcohol and malonate

Profiles of extracellular proteins of four fungi grown under the 50 -fold high $\mathrm{Mn}^{2+}$ level, with addition of $1 \mathrm{mM}$ veratryl alcohol and $10 \mathrm{mM}$ malonate, are shown in Figs. 3-6. Extracellular enzymes were also purified from $J$. separabilima cultures, but because of the low extracellular protein level produced by this fungus, the results are described in the text.

Enzyme activities were first assayed in eluted fractions and then the enzymes were analyzed by SDS-PAGE, native PAGE, and IEF using various staining procedures. Multiple $\mathrm{MnP}$ and laccase isoforms of $A$. biennis, Trametes hirsuta, Trametes gibbosa, and Trametes trogii were detected by enzyme activity staining of IEF gels. Isoenzyme patterns of Trametes gibbosa and Trametes trogii are shown in Fig. 7. In all elution profiles a distinct protein peak, designated P1 (Figs. 3-6), was observed, consisting of several unknown proteins the activity of which has not yet been defined. An absorption peak at $405 \mathrm{~nm}$ (hemeprotein) corresponding to protein peak P1 was also detected in all profiles. SDSPAGE separation of P1 showed the presence of several protein bands with molecular masses of the major proteins being 33 and $23 \mathrm{kDa}$. $\mathrm{H}_{2} \mathrm{O}_{2}$-producing activity, assayed with methylglyoxal, glucose, and cellobiose as substrates (22), was not found in the protein peak P1. Laccase activity corresponded to the protein peaks $\mathrm{P} 2$ (found in all fungi) and $\mathrm{P} 3$ (Trametes hirsuta). Two to three laccase isoforms with molecular masses of 68 to $64 \mathrm{kDa}$ and pIs of 4.0 to 3.7 were detected. In the IEF analysis, laccase but not $\mathrm{MnP}$ isoforms were stained with phenol red irrespective of the presence or absense of manganese in the substrate mixture (Fig. 7).

When comparing $\mathrm{LiP}$ and $\mathrm{MnP}$ isoenzyme profiles, fungal specific patterns were detected (Figs. 3-6). Two LiP isoforms with molecular masses of 44 and $41 \mathrm{kDa}$ and pIs of 3.7 and 3.8 were found and characterized in Trametes trogii (corresponding peaks $\mathrm{H} 5$ and $\mathrm{H} 4$ in Fig. 6). LiP activity was detected in the protein elution profile of Trametes gibbosa (corresponding peak $\mathrm{H} 1$ in Fig. 5). However, the lack of LiP staining in the IEF analysis was probaly due to the low enzyme amount and overlapping laccase activity (H1 in Fig. 7A). In the protein elution profiles of Trametes hirsuta and $A$. biennis, LiP was not identified. One possible reason for this could be the low levels of this enzyme expressed. The poor extracellular protein production in J. separabilima did not enable the detection of LiP in the elution profile. How- 
Fig. 2. (Evolution of ${ }^{14} \mathrm{CO}_{2}$ (泗) and production of ${ }^{14} \mathrm{C}$-labelled water-soluble compounds ( $\square$ ) by day 29 of DHP degradation by different white-rot fungi. Bars show standard deviations of four replicate cultures.

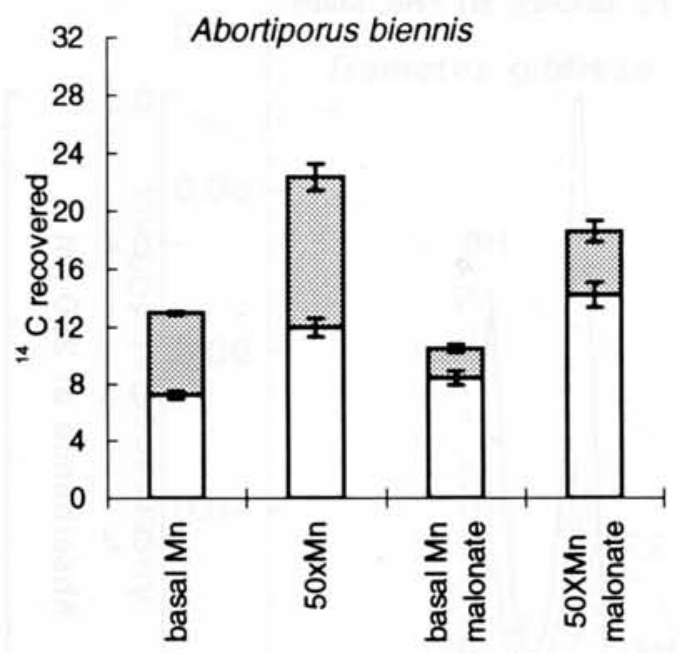

Trametes trogii
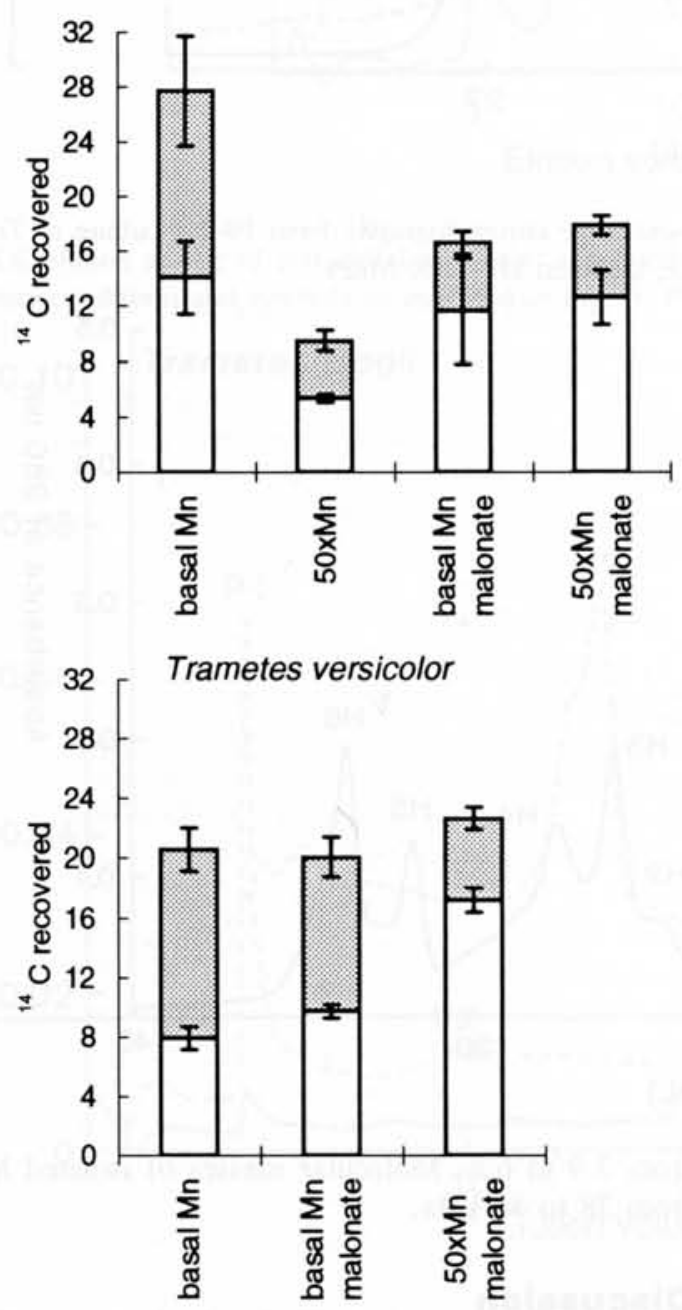

ever, under different culture conditions (high nitrogen and low manganese) three $\mathrm{LiP}$ isoforms were reported earlier in this species (52). Under the high $\mathrm{Mn}^{2+}$ conditions used in this study, one MnP isoenzyme, with a pI near 3.8 and showing a clear $\mathrm{Mn}^{2+}$-dependence of phenol red oxidizing in

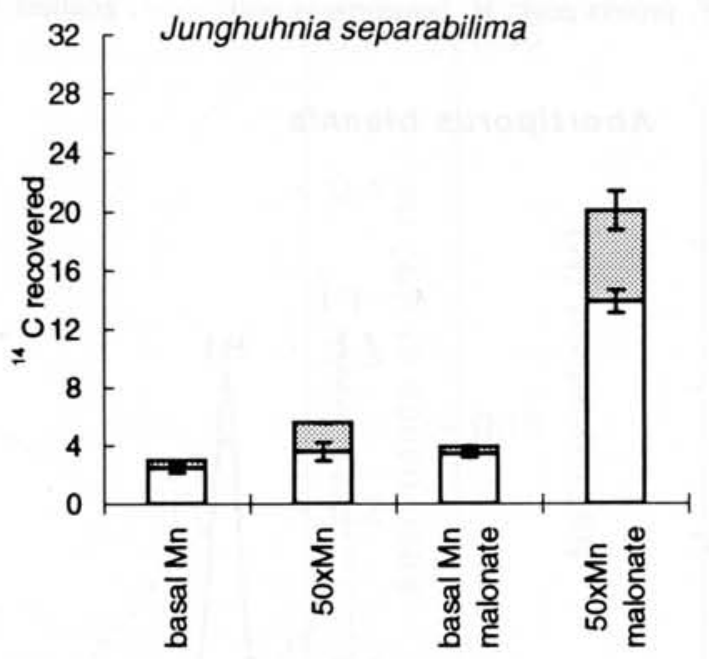

Trametes hirsuta

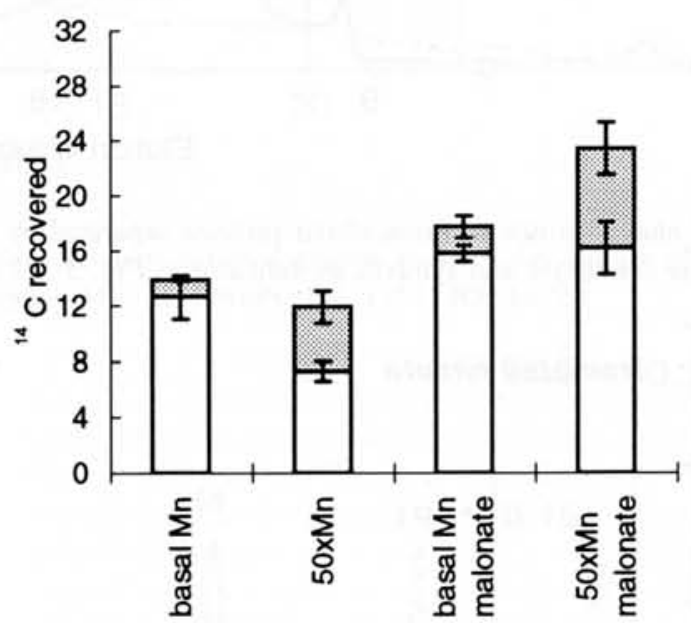

activity stainings, was purified from $J$. separabilima (results not shown). Thus, MnP was expressed in all fungi cultivated under high $\mathrm{Mn}^{2+}$ level with malonate addition. In most fungal species this ligninolytic enzyme was found in multiple forms that were eluted as different hemeproteins (Figs. 3- 
Fig. 3. FPLC elution profile of extracellular proteins separated by anion-exchange chromatography from 19-day culture of Abortiporus biennis supplemented with 50 -fold $\mathrm{Mn}^{2+}, 10 \mathrm{mM}$ malonate, and $1 \mathrm{mM}$ veratryl alcohol. -- , absorbance at $280 \mathrm{~nm}$; - absorbance at $405 \mathrm{~nm}$; $\mathrm{P}$, protein peak; $\mathrm{H}$, hemeprotein peak; $\cdots$, gradient $\mathrm{NaCl}$; $\mathrm{P} 2$, laccases; $\mathrm{H} 1-\mathrm{H} 6, \mathrm{MnPs}$.

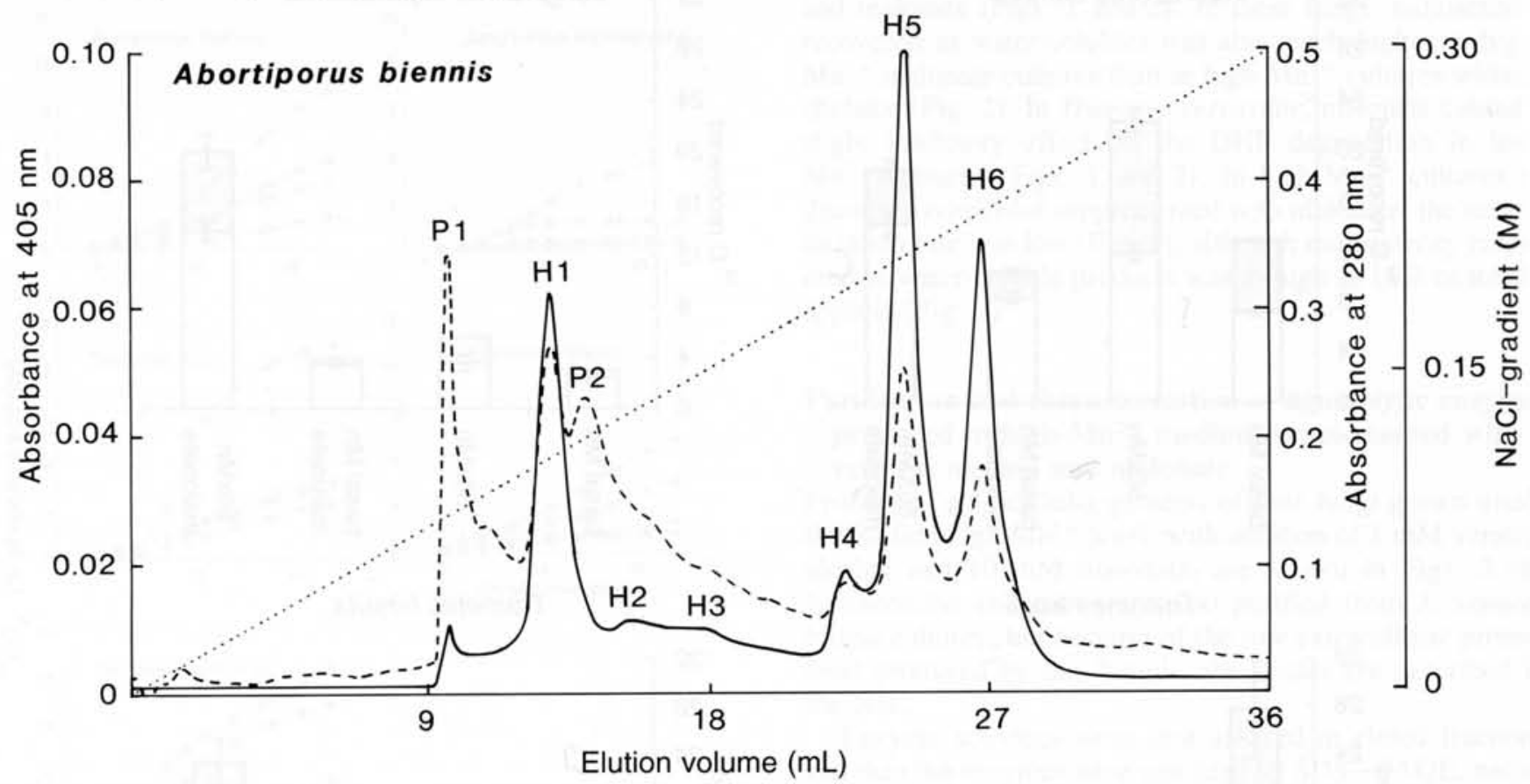

Fig. 4. FPLC elution profile of extracellular proteins separated by anion-exchange chromatography from 19-day culture of Trametes hirsuta. Culture conditions and symbols as indicated in Fig. 3. P2 and P3, laccases; H1-H6, MnPs.

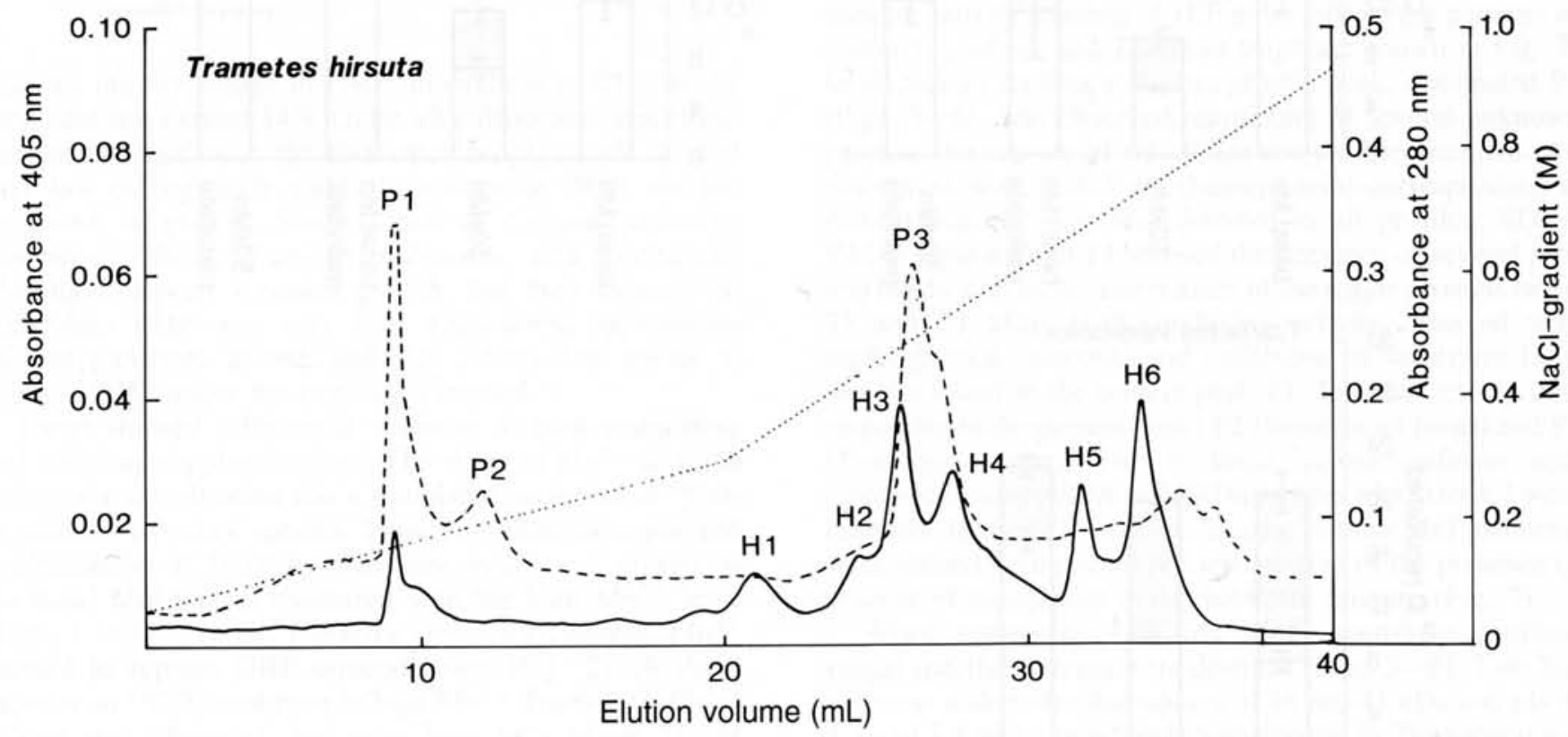

6). In addition, some of these hemeproteins showed a high degree of heterogeneity when analysed by IEF, resolving into numerous MnP proteins (Fig. 7). In the fungi belonging to the genus Trametes, these MnP isoforms could be further subdivided into a group of MnPs with relatively high $\mathrm{pI}$ values (ca. from 4.4 to 7.0) and a group of more acidic MnP isoforms consisting of two major proteins with pIs of 3.9-4.0 and 3.7-3.9, respectively. Abortiporus biennis produced a large number of $\mathrm{MnPs}$, which covered a pI range from 3.9 to 6.5. Molecular masses of isolated MnPs were from 38 to $45 \mathrm{kDa}$.

\section{Discussion}

Until recently, basic research on lignin degradation, e.g., its mechanisms, physiology, enzymology, and molecular biology, was mainly carried out on the white-rot basidiomycete Phanerochaete chrysosporium $(10,12,24-26,38,39,49$, 
Fig. 5. FPLC elution profile of extracellular proteins separated by anion-exchange chromatography from 19-day culture of Trametes gibbosa. Culture conditions and symbols as indicated in Fig. 3. P2, laccases; H1, LiP; H2, MnPs.

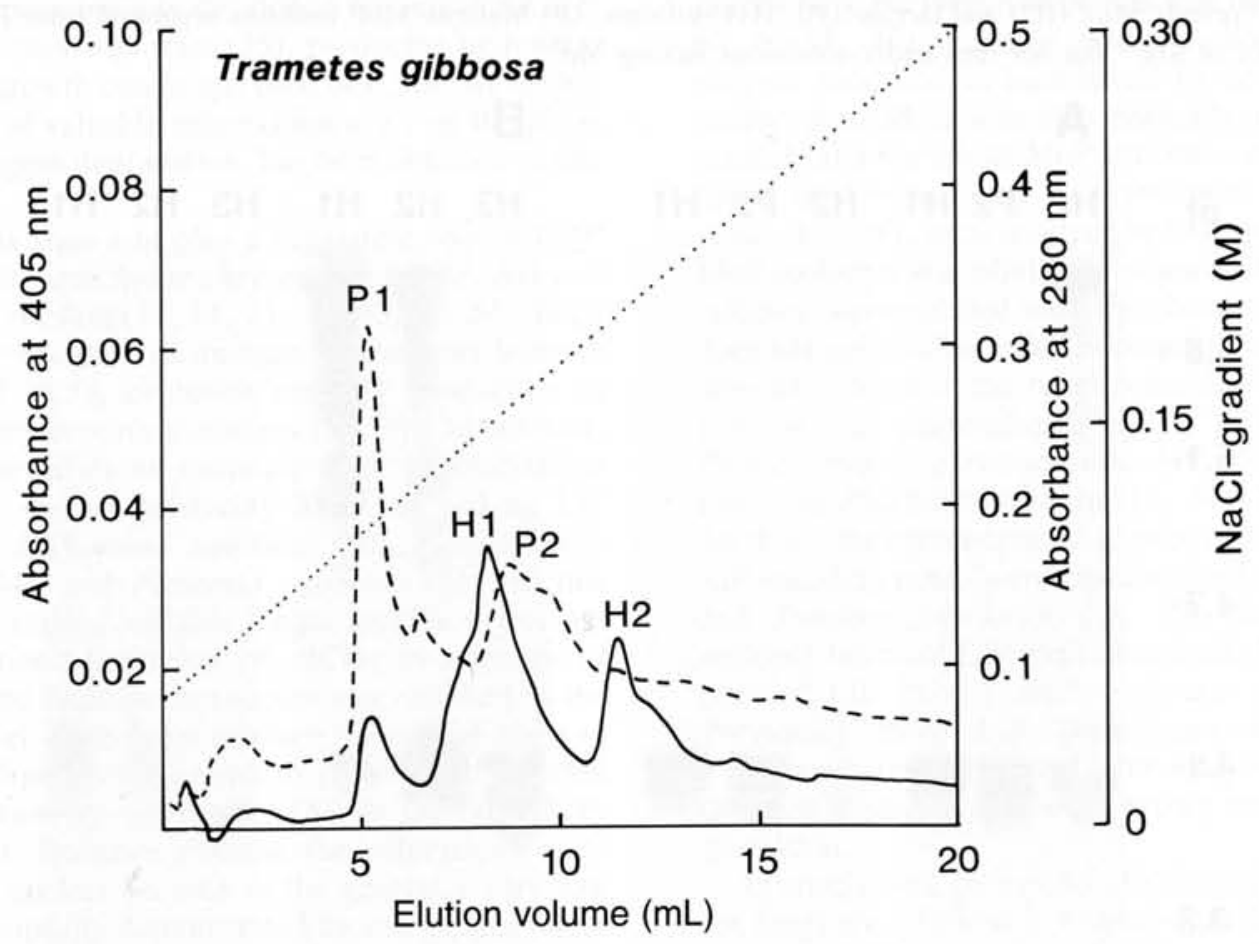

Fig. 6. FPLC elution profile of extracellular proteins separated by anion-exchange chromatography from 19-day culture of Trametes trogii. Culture conditions and symbols as indicated in Fig. 3. P2, laccases; H1-H3, MnPs; H4, LiP1; H5, LiP2.

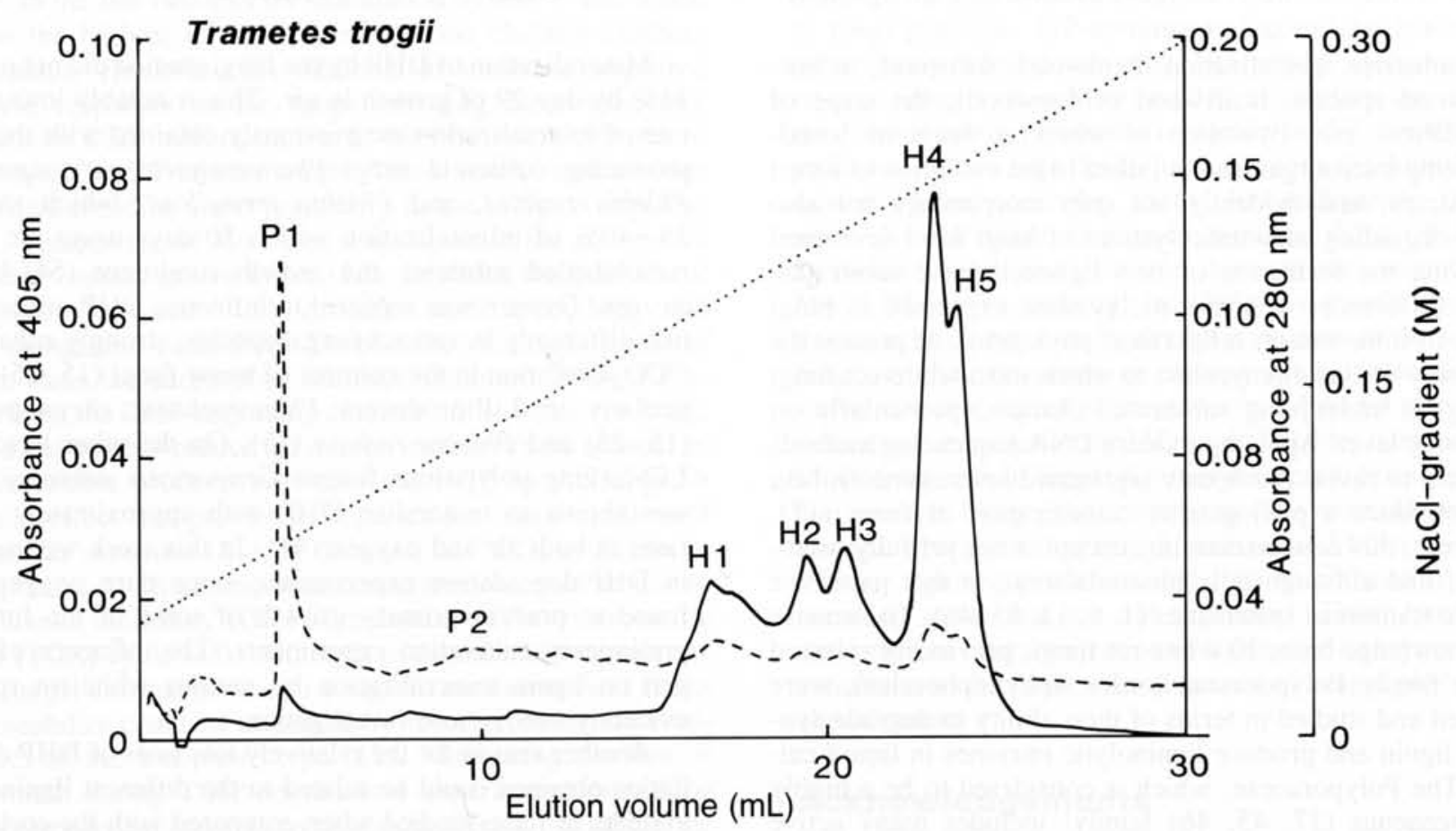

$50,56)$ belonging to the family Corticiaceae (order Aphyllophorales) $(1,17)$. However, data on ligninolytic activity and lignin-modifying enzymes of other white-rot fungi are accumulating $(5,10,14-16,18-21,29,32-36,40,43,44$, $47,51-55)$. These studies indicate that both the physiologi- cal conditions for lignin degradation and enzyme systems expressed are fungal specific and could differ from those found in Phanerochaete chrysosporium. This diversity provokes a number of questions. Are such differences connected with the taxonomic position and (or) ecology of the fungi, 
Fig. 7. Isoelectric focusing of ligninolytic enzymes purified from Trametes gibbosa and Trametes trogii. Protein (P) and hemeprotein $(\mathrm{H})$ peaks are designated as in Figs. 5 and 6. (A) Comparative staining of Trametes gibbosa enzymes with phenol red in the presence and absence of $\mathrm{Mn}^{2+}$ reveals $\mathrm{MnP}(\mathrm{H} 2)$ and laccase (P2, H1) isoforms. (B) Multiple $\mathrm{MnP}$ isoforms separated from Trametes trogii are stained in the presence of $\mathrm{Mn}^{2+}$ but not seen under conditions lacking $\mathrm{Mn}^{2+}$.

A

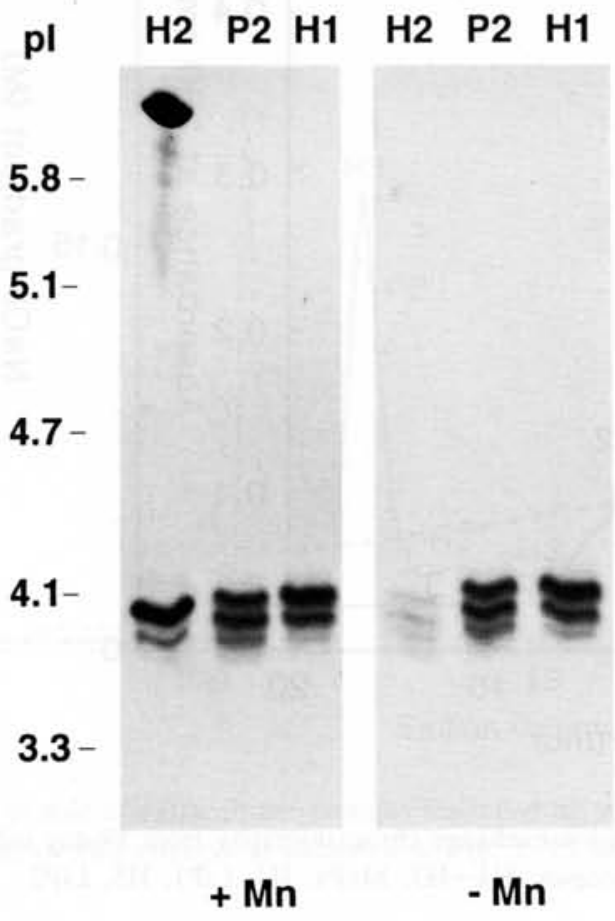

e.g., substrate specialization (hardwood, softwood, or certain wood species, heartwood or sapwood), the stage of degradation, etc. Evolution of white-rot fungi as woodinhabiting microorganisms is linked to the evolution of forest ecosystems, and evidently not only morphology but also lignin-degrading enzymatic systems of fungi were developed following the formation of new lignocellulosic substrates. Thus, differences in enzymatic systems expressed in fungi could, to some extent, reflect their phylogeny. At present the taxonomy of Basidiomycetes, to which most white-rot fungi belong, is undergoing substantial changes, particularly on the family level. Applying modern DNA sequencing methods will help to revise previously segregated heterogeneous taxa and introduce a phylogenetic classification of fungi (17). However, this new taxonomic concept is not yet fully established, and although it is unsatisfactory, in this paper we refer to traditional systematics $(1,6,13,45,46)$. To increase our knowledge base, 10 white-rot fungi, previously referred to the family Polyporaceae (order Aphyllophorales), were selected and studied in terms of their ability to degrade synthetic lignin and produce ligninolytic enzymes in liquid culture. The Polyporaceae, which is considered to be a highly heterogeneous $(17,45,46)$ family, includes many active lignin degraders, e.g., Bjerkandera adusta, Ceriporiopsis subvermispora, Cerrena unicolor, Ischnoderma resinosum, Pycnoporus cinnabarinus, Trametes gibbosa, Trametes hirsuta, Trametes versicolor $(3-6,17,45,46)$. Ligninolytic properties and enzymes of $B$. adusta $(20,23)$, Ceriporiopsis subvermispora $(5,43,44,47)$ and Trametes versicolor $(18$, $19,36,41)$ were recently investigated.
B

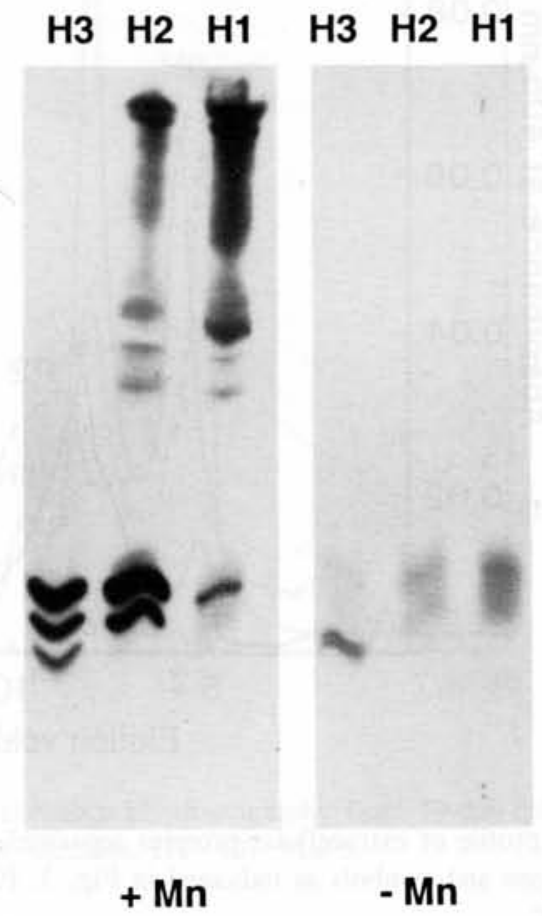

Mineralization of DHP by the fungi studied did not exceed $14 \%$ by day 29 of growth in air. This is notably lower than rate of mineralization we previously obtained with the LiPproducing corticioid fungi Phanerochaete chrysosporium, Phlebia radiata, and Phlebia tremellosa, which showed $35-40 \%$ of mineralization within 30 days using the same radiolabelled substrate and growth conditions (54) but in oxygen. Oxygen was reported to influence DHP mineralization differently in various fungal species, strongly enhancing ${ }^{14} \mathrm{CO}_{2}$ evolution in the cultures of many fungi $(15,25)$, particularly in LiP-producers Phanerochaete chrysosporium $(15,25)$ and Phlebia radiata (15). On the other hand, the LiP-lacking polyporous fungus Ceriporiosis subvermispora was shown to mineralize DHP with approximately equal rates in both air and oxygen (44). In this work we used air in DHP-degradation experiments, since pure oxygen was found to prevent primary growth of some of the fungi in preliminary cultivation experiments. The influence of oxygen on lignin mineralization by various white-rot species evidently needs more investigation.

Another reason for the relatively low rates of DHP degradation obtained could be related to the different ligninolytic systems of fungi studied when compared with the corticioid species Phanerochaete chrysosporium, Phlebia radiata, and Phlebia tremellosa, as was shown by the earlier reported results on DHP mineralization by Phanerochaete chrysosporium versus Ceriporiopsis subvermispora in liquid cultures and in wood (47). These observations indicated that the DHP assay may not reflect the true ligninolytic activity of many white-rot fungi growing under natural conditions, 
e.g., in wood substrates, that possess ligninolytic enzyme systems different from that of Phanerochaete chrysosporium. The DHP method was initially developed for liquid cultures of Phanerochaete chrysosporium (25), producing high titers of LiP under the growth conditions used $(49,50)$. Nevertheless, a great deal of valuable information e.g., on the physiology of fungal lignin degradation, has been obtained in this manner $(10,24)$.

Manganese was shown to play a regulative role in DHP degradation by Phanerochaete chrysosporium $(38,39)$ and some other white-rot fungi $(7,14,21,32,40,44,54)$. High $\mathrm{Mn}^{2+}$ level in the presense of manganese chelators leads to the repression of ${ }^{14} \mathrm{CO}_{2}$ evolution and $\mathrm{LiP}$ production in Phanerochaete chrysosporium cultures $(38,39)$. In contrast, higher $\mathrm{Mn}^{2+}$ concentrations stimulate DHP mineralization in several fungal species producing $\mathrm{MnP}$ but lacking LiP activity, such as Dichomitus squalens (40), Ceriporiopsis subvermispora (44), and Pleurotus ostreatus (21). In this study manganese caused variable fungal specific effects on DHP mineralization. Evolution of ${ }^{14} \mathrm{CO}_{2}$ in cultures of Trametes trogii and Trametes versicolor was inhibited by the 50 -fold $\mathrm{Mn}^{2+}$ level. Both fungi produce rather high titers of LiP, as has been found for Trametes trogii here and reported previously for Trametes versicolor (18). In the other LiPproducing species, Trametes gibbosa, the influence of manganese remained unclear because of the generally very low DHP-degrading capacity demonstrated by this fungus under the growth conditions used. Stimulation of DHP mineralization by the $\mathrm{Mn}^{2+}$ could indicate the participation of $\mathrm{MnP}$ in the case of A. biennis, J. separabilima, and Trametes hirsuta. In the last two species stimulation by $\mathrm{Mn}^{2+}$ was found to be the highest in the presence of the chelator (sodium malonate). However, the addition of malonate triggered diverse responses in the fungi, showing clear inhibitory effects on DHP mineralization in the $\mathrm{Mn}^{2+}$-low cultures of A. biennis and Trametes trogii. These results indicate that malonate could be a self-regulatory factor in lignin degradation, irrespective of $\mathrm{Mn}^{2+}$, as was shown in the cultures of Phlebia radiata grown in air (32), in which the addition of malonate decreased ${ }^{14} \mathrm{CO}_{2}$ evolution both under high- and low-manganese conditions. Despite the observation that in some cases the addition of malonate inhibited ${ }^{14} \mathrm{CO}_{2}$ evolution from the DHP-degrading cultures of the white-rot fungi, it did not notably reduce (or it even increased) the amount of water-soluble products derived from DHP by the fungi. A similar effect was previously reported for liquid cultures of Pleurotus ostreatus (21). A decrease of ${ }^{14} \mathrm{CO}_{2}$ evolution in the presence of high malonate concentration could be due to the known inhibitory effect of malonate on the tricarboxylic acid (TCA) cycle (48). Although malonate cannot penetrate the fungal cell membrane to a significant extent $(9,11)$, its permeability could be increased by forming molecular complexes of the ionophore type (11). Monitoring the fate of malonate during DHP-degradation experiments would be necessary to explain its physiological effects, including the possible metabolism of malonate by various fungi.

Different patterns of ligninolytic enzymes produced by the white-rot fungi grown under similar conditions in liquid cultures were observed even in taxonomically close species, e.g., among the fungi from the genus Trametes. Some of the investigated white-rot species (Trametes pubescens, Trichaptum abietinum, and G. applanatum) did not produce any notable ligninolytic activity and did not degrade synthetic lignin under the conditions studied, although in natural conditions they are known to be efficient lignin-degrading fungi $(4,6,45,46)$. Laccase was the most easily detectable enzyme produced in high levels by several species. Manganese peroxidase was also generally present in the fungi studied, and numerous $\mathrm{MnP}$ isoforms, similar to the pattern found in Ceriporiopsis subvermispora (43) and Trametes versicolor (18), were resolved in four species. Expression of $\mathrm{MnP}$ isoforms was obviously stimulated in high-manganese cultures supplemented with the chelator. Lignin peroxidase does not seem to be either widespread or easily produced in detectable titers in the fungi belonging to the Polyporaceae $(14,34)$, as demonstrated earlier in the corticioid fungi Phanerochaete chrysosporium $(49,50)$, Phlebia radiata (33), and Phlebia tremellosa $(15,54)$. The probable reason for this is the non-optimized growth conditions used. LiP and LiP encoding genes were characterized in $B$. adusta $(20,23)$ and Trametes versicolor $(18,19)$. In the latter fungus, multiple forms of LiP were described (19). In this work we purified LiP from Trametes gibbosa and Trametes trogii. Previously three LiP isoenzymes were isolated from J. separabilima (52), and now one $\mathrm{MnP}$ isoenzyme was detected in this fungus when grown under high $\mathrm{Mn}^{2+}$ concentration.

In conclusion, the results of this study showed that whiterot fungi are different in respect to their enzyme production patterns, DHP-degrading capacities, and regulation by $\mathrm{Mn}^{2+}$ or malonate. Extracellular peroxidases ( $\mathrm{LiP}$ and $\mathrm{MnP}$ ) were detected in DHP-degrading cultures of the fungi studied, although the role of these enzymes is still unclear. One group of fungi possesses LiP-dominating ligninolytic systems, the other group MnP-dominating ligninolytic systems, which involve either LiP or MnP in DHP mineralization. Fungi in the former group (Trametes versicolor and Trametes trogii) produced rather high levels of LiP, with the highest DHP mineralization occurring in the low-manganese medium, whereas DHP mineralization by the other fungi ( $A$. biennis, J. separabilima, and Trametes hirsuta) was stimulated by $\mathrm{Mn}^{2+}$. However, although no definitive conclusions about the connection between ligninolytic systems of the white-rot fungi and their taxonomy or ecology can be drawn from this study, a recent investigation of more white-rot species (51) indicates that evolutionary LiP might be older compared with $\mathrm{MnP}$. Evolution of fungal ligninolytic peroxidases needs further research using genetic methods. The more advanced and younger groups of fungi might utilize the MnP enzyme system for lignin degradation, but they might also have LiPencoding genes that are not expressed. Thus, biochemical data, such as characterization of ligninolytic enzymes, might contribute to the further development of fungal phylogenetic classification.

\section{Acknowledgements}

This study was supported by the Academy of Finland (grants nos. 1011244 and 8342 for EU AIR 2-CT93-1219). We thank Thomas Johansson (Department of Biochemistry, University of Lund, Sweden) for providing Trametes versicolor strain PRL 572, Mika Kalsi (Department of Applied Chemistry and Microbiology, University of Helsinki) for excellent technical assistance, Antti Uusi-Rauva and Kaj- 
Roger Hurme (Isotope Laboratory, Faculty of Agriculture and Forestry, University of Helsinki) for technical help in the DHP mineralization experiments, Sari Galkin (Department of Applied Chemistry and Microbiology, University of Helsinki) and Gösta Brunow (Department of Chemistry, University of Helsinki) for providing the nonlabelled DHP, Taina Lundell (Department of Applied Chemistry and Microbiology, University of Helsinki) for valuable comments, and Robin Sen (Division of General Microbiology, Department of Biosciences, University of Helsinki) for helpful linguistic revision of the manuscript.

\section{References}

1. Ainsworth, G.C., Sparrow, F.K., and Sussman, A.S. 1973. The fungi. Vol. IVB. A taxonomic review with keys: Basidiomycetes and lower fungi. Academic Press, New York.

2. Blanchette, R.A. 1984. Manganese accumulation in wood decayed by white-rot fungi. Phytopathology, 74: 153-160.

3. Blanchette, R.A. 1984. Screening wood decayed by white-rot fungi for preferential lignin degradation. Appl. Environ. Microbiol. 48: 647-653.

4. Blanchette, R.A. 1995. Degradation of the lignocellulose complex in wood. Can. J. Bot. 73 (Suppl. 1): S999-S1010.

5. Blanchette, R.A., Burnes, T.A., Eerdmans, M.M., and Akhtar, M. 1992. Evaluating isolates of Phanerochaete chrysosporium and Ceriporiopsis subvermispora for use in biological pulping processes. Holzforschung, 46: 109-115.

6. Bondarcev, A. 1953. The Polyporaceae of the European USSR and Caucasia. [In Russian.] Academy of Science USSR, Moscow, Russia.

7. Bonnarme, P., and Jeffries, T.W. 1990. Mn(II) regulation of lignin peroxidases from lignin-degrading white-rot fungi. Appl. Environ. Microbiol. 56: 210-217.

8. Bradford, M.M. 1976. A rapid and sensitive method for the quantitation of microgram quantities of protein utilizing the principle of protein dye binding. Anal. Biochem. 72: 248-254.

9. Burnett, J.H. 1976. Fundamentals of mycology. Edward Arnold (Publishers) Ltd., London, U.K.

10. Eriksson, K.-E., Blanchette, R.A., and Ander, P. 1990. Microbial and enzymatic degradation of wood and wood components. Springer-Verlag, Berlin, Germany.

11. Gennis, R.B. 1989. Biomembranes: molecular structure and function. Springer-Verlag, New York.

12. Gold, M.H., and Alic, M. 1993. Molecular biology of the lignin-degrading basidiomycete Phanerochaete chrysosporium. Microbiol. Rev. 57: 605-622.

13. Hallenberg, N. 1991. Speciation and distribution in Corticiaceae (Basidiomycetes). Plant Syst. Evol. 177: 93-110.

14. Hatakka, A. 1994. Lignin-modifying enzymes from selected white-rot fungi: production and role in lignin degradation. FEMS Microbiol. Rev. 13: 125-135.

15. Hatakka, A., and Uusi-Rauva, A. 1983. Degradation of ${ }^{14} \mathrm{C}$ labelled poplar wood lignin by selected white-rot fungi. Eur. J. Appl. Microbiol. Biotechnol. 17: 235-242.

16. Hatakka, A., Niemenmaa, O., and Lundell, T. 1993. Production and characterization of lignin peroxidases and laccase from the white-rot fungi Phlebia radiata and Phlebia (Merulius) tremellosa. In Lignocellulosics: science, technology, development and use. Edited by J.F. Kennedy, G.O. Phillips, and P.A. Williams. Ellis Horwood Ltd., Chichester, U.K. pp. 154-156.

17. Hibbett, D.S., and Donoghue, M.J. 1994. Progress toward a phylogenetic classification of the Polyporaceae through parsimony analysis of mitochondrial ribosomal DNA sequences. Can. J. Bot. 73 (Suppl. 1): S853-S861.

18. Johansson, T., and Nyman, P.O. 1993. Isozymes of lignin peroxidase and manganese(II) peroxidase from the white-rot basidiomycete Trametes versicolor. I. Isolation of enzyme forms and characterization of physical and catalytic properties. Arch. Biochem. Biophys. 300: 49-56.

19. Jönsson, L. 1994. Lignin peroxidase from the wood-degrading basidiomycete Trametes versicolor: studies on enzymatic properties and gene structure. Ph.D. thesis, Department of Biochemistry, University of Lund, Lund, Sweden.

20. Kaal, E.E.J., de Jong, E., and Field, J.A. 1993. Stimulation of ligninolytic peroxidase activity by nitrogen nutrients in the white rot fungus Bjerkandera sp. Appl. Environ. Microbiol. 59: $4031-4036$.

21. Kerem, Z., and Hadar, Y. 1993. Effect of manganese on lignin degradation by Pleurotus ostreatus during solid-state fermentation. Appl. Environ. Microbiol. 59: 4115-4120.

22. Kersten, P.J., and Kirk, T.K. 1987. Involvement of a new enzyme, glyoxal oxidase, in extracellular $\mathrm{H}_{2} \mathrm{O}_{2}$ production by Phanerochaete chrysosporium. J. Bacteriol. 169: 2195-2201.

23. Kimura, Y., Asada, Y., Oka, T., and Kuwahara, M. 1991. Molecular analysis of a Bjerkandera adusta lignin peroxidase gene. Appl. Microbiol. Biotechnol. 35: 510-514.

24. Kirk, T.K., and Farrell, R.L. 1987. Enzymatic combustion: the microbial degradation of lignin. Annu. Rev. Microbiol. 41: $465-505$.

25. Kirk, T.K., Schultz, E., Connors, W.J., Lorenz, L.F., and Zeikus, J.G. 1978. Influence of culture parameters on lignin metabolism by Phanerochaete chrysosporium. Arch. Microbiol. 117: $277-285$.

26. Kuwahara, M., Glenn, J.K., Morgan, M.A., and Gold, M.H. 1984. Separation and characterization of two extracellular $\mathrm{H}_{2} \mathrm{O}_{2}$-dependent oxidases from ligninolytic cultures of Phanerochaete chrysosporium. FEBS Lett. 169: 247-250.

27. Laemmli, U. 1976. Cleavage of structural proteins during the assembly of the head of bacteriophage T4. Nature (London), 227: $670-685$

28. Lamar, R.T., Glaser, J.A., and Kirk, T.K. 1992. White-rot fungi in the treatment of hazardous chemicals and wastes. In Frontiers of industrial mycology. Edited by G.F. Leatham. Chapman and Hall, New York. pp. 127-143.

29. Lundell, T., Leonowicz, A., Rogalski, J., and Hatakka, A. 1990. Formation and action of lignin-modifying enzymes in cultures of Phlebia radiata supplemented with veratric acid. Appl. Environ. Microbiol. 56: 2623-2629.

30. Martínez A.T., Camarero S., Guillén F., Gutiérrez, A., Muñoz C., Varela, E., Martínez, M.J., Barrasa, J.M., Ruel, K., and Pelayo J.M. 1994. Progress in biopulping of nonwoody materials: chemical, enzymatic and ultrastructural aspects of wheat straw delignification with ligninolytic fungi from the genus Pleurotus. FEMS Microbiol. Rev. 13: 265274.

31. Messner, K., and Srebotnik, E. 1994. Biopulping: an overview of developments in an environmentally safe paper-making technology. FEMS Microbiol. Rev. 13: $351-364$.

32. Moilanen, A.-M., Lundell, T., Vares, T., and Hatakka, A. 1996. Manganese and malonate are individual regulators for the production of lignin and manganese peroxidase isozymes and in the degradation of lignin by Phlebia radiata. Appl. Microbiol. Biotechnol. 45: 792-799.

33. Niku-Paavola, M.-L., Karhunen, E., Salola, P., and Raunio, V. 1988. Ligninolytic enzymes from the white-rot fungus Phlebia radiata. Biochem. J. 254: 877-884.

34. Orth, A.B., Royse, D.J., and Tien, M. 1993. Ubiquity of lignin-degrading peroxidases among various wood-degrading fungi. Appl. Environ. Microbiol. 59: 4017-4023.

35. Otjen, L., and Blanchette, R. 1987. Assessment of 30 white rot basidiomycetes for selective lignin degradation. Holzforschung, 41: $343-349$. 
36. Paice, M.G., Reid, I.D., Bourbonnais, R., Archibald, F.S., and Jurasek, L. 1993. Manganese peroxidase, produced by Trametes versicolor during pulp bleaching, demethylates and delignifies kraft pulp. Appl. Environ. Microbiol. 59: 260265.

37. Pease, E.A., Aust, S.D., and Tien, M. 1991. Heterologous expression of active manganese peroxidase from Phanerochaete chrysosporium using the Baculovirus expression system. Biochem. Biophys. Res. Commun. 179: 897-903.

38. Perez, J., and Jeffries, T.W. 1990. Mineralization of ${ }^{14} \mathrm{C}$-ringlabeled synthetic lignin correlates with the production of lignin peroxidase, not of manganese peroxidase or laccase. Appl. Environ. Microbiol. 56: 1806-1812.

39. Perez, J., and Jeffries, T.W. 1992. Roles of manganese and organic acid chelators in regulating lignin degradation and biosynthesis of peroxidases by Phanerochaete chrysosporium. Appl. Environ. Microbiol. 58: 2402-2409.

40. Périé, F.H., and Gold, M.H. 1991. Manganese regulation of manganese peroxidase expression and lignin degradation by the white rot fungus Dichomitus squalens. Appl. Environ. Microbiol. 57: 2240-2245.

41. Reid, I.D., and Paice, M.G. 1994. Biological bleaching of kraft pulps by white-rot fungi and their enzymes. FEMS Microbiol. Rev. 13: $369-376$.

42. Ruel, K., Ambert, K., and Joseleau, J.-P. 1994. Influence of the enzyme equipment of white-rot fungi on the patterns of wood degradation. FEMS Microbiol. Rev. 13: 241-254.

43. Rüttimann, C., Salas, L., and Vicuña, R. 1992. Studies on the ligninolytic system of the white-rot fungus Ceriporiopsis subvermispora. In Biotechnology in pulp and paper industry. Proceedings of the 5th International Conference on Biotechnology in the Pulp and Paper Industry, Kyoto, May 27-30, 1992. Edited by M. Kuwahara and M. Shimada. Uni Publishers Co., Ltd., Tokyo, Japan. pp. 243-248.

44. Rüttimann-Johnson, C., Salas, L., Vicuña, R., and Kirk, T.K. 1993. Extracellular enzyme production and synthetic lignin mineralization by Ceriporiopsis subvermispora. Appl. Environ. Microbiol. 59: 1792-1797.
45. Ryvarden, L., and Gilbertson, R.L. 1993. European Polypores. Part 1. Gronlands Grafiske A/S, Oslo, Norway.

46. Ryvarden, L., and Gilbertson, R.L. 1994. European Polypores. Part 2. Gronlands Grafiske A/S, Oslo, Norway.

47. Srebotnik, E., Jensen, K.A., Jr., and Hammel, K.E. 1994. Fungal degradation of recalcitrant nonphenolic lignin structures without lignin peroxidase. Proc. Natl. Acad. Sci. U.S.A. 91: $12794-12797$.

48. Stryer, L. 1988. Biochemistry. W.H. Freeman and Co., San Francisco, Calif.

49. Tien, M., and Kirk, K. 1983. Lignin-degrading enzyme from the hymenomycete Phanerochaete chrysosporium Burds. Science (Washington, D.C.), 221: 661-663.

50. Tien, M., and Kirk, K. 1988. Lignin peroxidase of Phanerochaete chrysosporium. Methods Enzymol. 161B: 238-249.

51. Vares, T. 1996. Ligninolytic enzymes and lignin-degrading activity of taxonomically different white-rot fungi. Ph.D. thesis, Department of Applied Chemistry and Microbiology, University of Helsinki, Helsinki, Finland.

52. Vares, T., Lundell, T.K., and Hatakka, A.I. 1992. Novel heme-containing enzyme possibly involved in lignin degradation by the white-rot fungus Junghuhnia separabilima. FEMS Microbiol. Lett. 99: 53-58.

53. Vares, T., Lundell, T.K., and Hatakka, A.I. 1993. Production of multiple lignin peroxidases by the white-rot fungus Phlebia ochraceofulva. Enzyme Microb. Technol. 15: 664-669.

54. Vares, T., Niemenmaa, O., and Hatakka, A. 1994. Secretion of ligninolytic enzymes and mineralization of ${ }^{14} \mathrm{C}$-ring-labelled synthetic lignin by three Phlebia tremellosa strains. Appl. Environ. Microbiol. 60: 569-575.

55. Vares, T., Kalsi, M., and Hatakka, A. 1995. Lignin peroxidases, manganese peroxidases, and other ligninolytic enzymes produced by Phlebia radiata during solid-state fermentation of wheat straw. Appl. Environ. Microbiol. 61: 3515-3520.

56. Wariishi, H., Valli, K., and Gold, M.H. 1992. Manganese(II) oxidation by manganese peroxidase from the basidiomycete Phanerochaete chrysosporium. Kinetic mechanism and role of chelators. J. Biol. Chem. 267: $23688-23695$. 